\title{
Varieties and drivers of social welfare in sub-Saharan Africa: A critical assessment of current research
}

\author{
Daniel KÜNZLER', Michael NOLLERT ${ }^{2}$ \\ University of Fribourg
}

\begin{abstract}
How can we conceptually grasp social policies on the macro level in sub-Saharan Africa? Decommodification and defamilialisation, two key concepts of EspingAndersen's seminal typology, are not very helpful to distinguish welfare regimes in sub-Saharan Africa. Moreover, typologies that have been developed for the Global South hardly consider social stratification. In conclusion, there is no typology including African states that covers all relevant dimensions of welfare and includes education, agricultural, and housing policies. There is also more need for comparative research on the drivers of social policies and especially policies that are more likely to reduce inequality.
\end{abstract}

Keywords: regimes of social welfare, sub-Saharan Africa, politics of social policy, typologies

\section{Introduction}

The first of the UN Sustainable Development Goals aims at ending "poverty in all its forms everywhere". Associated with this goal is the target to "implement nationally appropriate social protection systems and measures for all" and achieve "substantial coverage of the poor and the vulnerable" by 2030 (UN 2015: n.p.). Such social protection systems are among the topics discussed in the burgeoning literature on social policy. This contribution is interested in a question that is somewhat treated as an orphan in social policy literature: How can we conceptually grasp social policies on the macro level in sub-Saharan Africa?

\footnotetext{
${ }^{1}$ Daniel Künzler, Dr., University of Fribourg, Department of Social Sciences, Route des Bonnesfontaines 11, CH-1700 Fribourg, daniel.kuenzler@unifr.ch. Daniel Künzler is lecturer in sociology, social policy and social work at the University of Fribourg. His research focuses on social policy in sub-Saharan Africa and popular culture, with a special focus on Eastern Africa.

${ }^{2}$ Michael Nollert, Prof. Dr., University of Fribourg, Department of Social Sciences, Division of Sociology, Social Policy and Social Work. Route des Bonnesfontaines 11, CH-1700 Fribourg, michael.nollert@unifr.ch. His research and publications focus on social inequalities, social networks, labour markets, unpaid work, economic sociology and social conflicts.
} 
The starting point for many reflections on this question is Esping-Andersen's (1990) ground-breaking work that was meant to describe Western capitalist societies. In his analysis of welfare state formation in Europe, he distinguished "qualitatively different arrangements between state, market, and the family" regarding the provision of welfare (Esping-Andersen 1990: 26). Neglecting the contributions of non-profit organisations and without using cluster analysis, he proposed three regime-types: liberal, corporatist, and social democratic welfare states. A first key variable for constructing his famous typology is decommodification. Decommodification is defined as "the degree to which individuals, or families, can uphold a socially acceptable standard of living independently of market participation" (Esping-Andersen 1990: 37). It is measured as the degree of social protection against poverty-related risks of the commodification and marketisation of manpower. Social stratification is the second key dimension of welfare regimes (Esping-Andersen 1990: 55). Thus, countries vary according to their level of inequalities in life chances and in the distribution of income and wealth (money, land, estate).

The first cluster contains the liberal welfare regimes, such as Australia, Canada, and the United States. In these highly stratified countries, work is preferred to entitlement and welfare is predominantly based on "means-tested assistance, modest universal transfer, or modest social-insurance" (Esping-Andersen 1990: 26). There are minimal decommodification effects, as the market is central and both the state and the family are marginal (Esping-Andersen 1999: 85). Clustered in the second type are the corporatist welfare regimes, such as Austria, France, Germany and Italy. This type is frequently called conservative welfare state, as the family is central, the market is marginal, and the state is subsidiary. There is a high decommodification for male wage earners and a medium stratification as benefits depend on occupational status. Finally, the third type contains social democratic welfare regimes where the welfare state is central and the family and the market marginal. These regimes promote a low stratification, indicated by measures of economic inequality and social mobility, and high decommodification.

However, "welfare states may be equally large or comprehensive, but with entirely different effects on social structure. One may cultivate hierarchy and status, another dualisms, and a third universalism" (Esping-Andersen 1990: 58). After being criticised for neglecting gender aspects (Bambra 2004, 2007), Esping-Andersen (1999: 51) emphasised in a revision the concept of defamilialisation as the third key dimension. Defamilialisation or defamilisation (Bambra 2004) is the extent to which household welfare and care is provided by the state or through market measures and, thus, not by the household. Defamilialisation is high in the social democratic cluster, medium in the liberal, and low in the corporatist. However, while the social-democratic regimes focus on working mothers with children, liberal regimes support career aspirations of highly qualified women (Mandel 2009).

The typology of Esping-Andersen triggered a considerable discussion about the discriminatory power and stability of the three regimes (Nollert 2006, Danforth 2014, Deeming 2017). Other questions raised were the character of welfare regimes beyond the 18 OECD countries included in the initial study and the usefulness of Esping-Andersen's key variables. ${ }^{3}$ Does it

\footnotetext{
${ }^{3}$ Trucco discusses the Turkish case in this edition of socialpolicy.ch.
} 
make sense to use his typology in analysing the varieties of welfare regimes in the Global South? These questions were the starting point of an international workshop on social policy and regimes of social welfare in Africa organised by the authors at the University of Fribourg in September 2014. ${ }^{4}$ The papers in this issue were partly developed from presentations held at this workshop and focus on South Africa, Namibia, and Botswana. We start looking at the typology of Esping-Anderson and its key concepts from the sub-Saharan African context. The second section presents other typologies that have been developed for the Global South, in general, and the sub-Saharan African context, in particular. Although these typologies suggest a large variety of social welfare in Africa, social stratification is hardly considered in comparative research. The third section turns to welfare research that discusses whether targeting or universal social welfare is more likely to reduce inequality. The potential drivers of such social policies are in focus of the fourth section. We argue that theoretical perspectives developed for the Global North have to be adjusted in the context of the Global South. We conclude in the final section that there is no typology of African states that covers all important dimensions of welfare and there is more need for comparative research on the drivers of social policies in these contexts.

\section{Applying Esping-Andersen to sub-Saharan Africa?}

How useful is Esping-Andersen's concept for the Global South in general and sub-Saharan Africa in particular? Very few would apply the regime typology directly to African countries. Seekings and Nattrass (2015: 21), for example, describe South Africa as an uneasy combination of social democratic and neoliberal elements (for a different reasoning on the South African case, see the contribution of Noyoo in this issue). Social democracy is not a political project in South Africa whose ruling party rather prefers to refer to a developmental state. However, there are some features associated with social democracy, such as institutions for collective bargaining over wages and conditions of employment, social housing, or decommodifying forms of non-contributory tax-financed social assistance, such as the child support grant. However, economic inequality in South Africa is even larger than in liberal regimes and, therefore, does absolutely not fit social democratic egalitarianism.

While Esping-Andersen might have some heuristic value for the South African case, his key categories are difficult to apply in the sub-Saharan African context. First, while we can refer to data on wealth and income inequalities in Southern Africa, there is a lack of information on the social stratification in many other sub-Saharan countries. Second, defamilialisation has a quite different meaning in the African context. There is a widespread understanding that the ideal extended family respects norms of reciprocity and is central to the welfare of people. It should not be undermined by the state or by individualism. In line with the concept of subsidiarity, only when the family fails has the state a responsibility to

\footnotetext{
${ }^{4}$ The authors would like to thank the Swiss Academy of Humanities and Social Sciences, the Swiss National Science Foundation, the Carl Schlettwein Foundation, the Swiss Society for African Studies, and the University of Fribourg for financial support of the workshop.
} 
substitute for it (Seekings 2017). ${ }^{5}$ Finally, also the notion of the state is different. While notions such as weak, shadow, or collapsed states (Wood and Gough 2006: 1700) are problematic, they point to an important difference: compared to the OECD countries included in the Esping-Andersen dataset, the bureaucracy ${ }^{6}$ is much weaker in most sub-Saharan African states. South Africa, Botswana, and Namibia - the countries discussed in the other contributions of this issue - are among the sub-Saharan countries with a comparatively high state capacity.

Third, there are also several problems with the concept of decommodification. The notion implicitly assumes a high level of commodification, both in the sense of a formal labour market with full employment and a market for (health) care and pension insurances. Regarding the first aspect, the formal labour market is generally less important than the informal (ILO 2013: 8). The share of informal employment as a percentage of total non-agricultural employment in South Africa is at $36.8 \%$ for women and $29.5 \%$ for men, in Namibia at $47 \%$ for women and 41.1\% for men (ILO 2013: 12). For Botswana, no data are reported. Although data are notoriously unreliable and incomplete, it is not disputed that the Southern African countries are rather exceptions in the African context. Generally, the share is higher in other regions of Africa where the dominant form of employment, also in agriculture, is not the permanent participation in a formal labour market, but self-employment, seasonal, or casual labour. In a nutshell, having a formal job is rather the exception in a context where most earn a "portfolio of livelihoods" (Wood and Gough 2006: 1700). Commodification through increased participation in the formal labour market in this context is one way of increasing welfare. The idea of decommodification furthermore "fails to account for the 'supply-side' of the model" (Adésínà 2015: 102). All forms of social welfare, be they tax-funded or financed through contributions, require funds that are based on employment relations. Generally, the policies of sub-Saharan African countries aim at commodification to provide growing employment and broaden the tax base. Employment, however, is not necessarily based on participation in the formal labour market and the limited social protection it offers. Employment outside the formal labour market is frequently too precarious to allow for significant investments in market-based social welfare. Furthermore, there is low trust in both forms of social protection.

\section{Varieties of sub-Saharan African welfare regimes}

A number of authors developed typologies that included or focused on sub-Saharan African countries. As discussed in the first sub-section, global typologies suggest a variety of regime typologies. In several typologies, sub-Saharan African countries are members of different types that cover different world regions. In contrast, one typology groups a number of almost exclusively sub-Saharan African countries into one regime type, the Insecurity Regimes. How-

\footnotetext{
${ }^{5}$ It is important to also bear in mind that the age structure is quite different in sub-Saharan Africa compared to the OECD world, with important consequences for care work and pensions. According to the data listed in the CIA World Factbook (n.d.), the medium age is under 20 years in several sub-Saharan African countries and above 40 years in Europe. South Africa is at 26.8 years, Botswana at 23.2, and Namibia at 21 years.

${ }^{6}$ Bureaucracy is measured by personal, financial resources and the capability to tax citizens.
} 
ever, these typologies generally include only a few sub-Saharan African countries and lack data on social stratification. As discussed in the second sub-section, typologies with a focus on sub-Saharan countries stress other dimensions of social protection, thus questioning the application of Esping-Andersen's concept.

\section{African countries in global typologies}

Although not applied directly to countries in the Global South in general and sub-Saharan Africa in particular, Esping-Andersen's work proved to be inspiring for a number of alternative typologies. The cluster analysis of Wood and Gough (2006) does not use indicators of decommodification, social stratification and defamilialisation. ${ }^{7}$ It reveals four clusters that each includes countries from at least two different world regions. African countries are part of three clusters. Nevertheless, in the subsequent discussion these nuances are dismissed and the countries of different world regions are reduced to the following taxonomy (Wood and Gough 2006: 1706). Korea and Taiwan are labelled Emerging Productivist Welfare States and situated close to the welfare state regimes. Beyond these, the authors identify two meta-welfare regimes: Informal Security regimes and Insecurity regimes.

Informal Security Regimes are divided in three sub-regimes: Informal Security Regimes, Liberal-Informal Welfare States and an unlabelled group of South Asian states. In all of these three sub-regimes, "people rely heavily upon community and family relationships to meet their security needs, to greatly varying degrees" as these relationships are frequently hierarchical and asymmetrical (Wood and Gough 2006: 1699). For our concern more interesting is the second meta regime: Insecurity regimes. Although sub-Saharan Africa empirically fitted into three clusters, based on the work of Bevan (2004), the discussion reduces all countries of this region to Insecurity regimes. In these regimes, the state contributes to insecurity and destroys household coping mechanisms. Welfare is mainly based on precarious informal arrangements, supplemented by occasional activities of civil society actors. While this perspective cements stereotypes about dysfunctional African states and widespread misery in Africa, it is in line with the core argument of social historian Iliffe (1987), who described the African poor as having to rely on themselves, their extended family, religious institutions, or, in times of war or famine, on the international community. The first is called Informal Security Regimes. In these regimes, Thus, as Wood and Gough (2006), he assumes there is no welfare state in sub-Saharan Africa. However, Wood and Gough (2006) have a limited and somewhat biased sample of African countries and neither South Africa nor Botswana and Namibia are part of the sample.

A follow-up study raised two important points (Abu Sharkh and Gough 2010: 28). Firstly, the welfare mix must be extended beyond the state, the market, and the family and include community-based relationships and NGOs. However, this is notoriously difficult to operationalise (e.g. Salamon, Sokolowski and Haddock 2017). Secondly, the welfare mix must also include transnational actors such as international organisations or migrants as providers of welfare. Here, data are more easily available. The study also uses data on public spending on

\footnotetext{
${ }^{7}$ Instead, variables such as the Human Development Index, public spending on health and education as a share of GDP, and the sum of international inflows of aid and remittances as a share of GNP are used.
} 
education plus healthcare as a share of GDP, on social security contributions as a share of total government revenues, on immunisation against measles and female secondary school enrolment. The cluster analysis was done for 1990 and 2000. It confirms the meta-welfare regimes mentioned above but differentiates between relatively successful and failing informal security regimes. Some countries are in different clusters in the two points of time.

Closest to welfare states of Esping-Andersen and replacing the Emerging Productivist Welfare States of the earlier analysis are the countries grouped as Proto-Welfare States. Stably in this cluster are mainly formerly socialist European countries, Israel, and a few Latin American countries (Costa Rica, Brazil, Uruguay, Argentina). These countries are committed to welfare provision and deliver services relatively effective. Although economic inequalities are not considered, however, we have to mention large differences in inequality between these countries. Among the countries stably in the Successful Informal Security Regimes type are several Latin American and Asian countries, as well as Turkey, Iran, and Tajikistan. In these countries, the welfare outcomes are relatively good but based on low levels of state spending. There are two clusters of Failing Informal Security Regimes. The first, being characterised by high illiteracy, is mainly on the Indian sub-continent. The second is marked by high morbidity, especially as a result of HIV/AIDS, which undermines relatively high government expenditures. Namibia is stably in this cluster, South Africa and Botswana dropped from being a Successful Informal Security Regime in 1990 to a Failing Informal Security Regime in 2000. All three countries still perform above the African average. Again, the other sub-Saharan African countries part of the sample are generally considered Insecurity Regimes, dependent on overseas aid, with low levels of public spending and life expectancy.

Rudra's cluster analysis (2007) includes government expenditures on education and health as a proportion of the total budget of the state and the literacy, mortality, and immunisation rates. The extent of public employment, spending on social security and welfare, housing subsidies, labour market protections, and investment in tertiary education are used to measure the extent the state protects workers from market risks. While the clusters include a few African countries, South Africa, as well as Botswana and Namibia, are missing. The analysis reveals a cluster that is interpreted as productive and includes a single African country, Mauritius. ${ }^{8}$ These countries promote participation in the formal labour market and encourage, with their limited social policies, competitiveness on export markets. In contrast, the countries in the cluster of protective welfare states protect companies and their workers from international competition. Social policies focus on decommodification. This cluster includes Turkey, Morocco, Tunisia, Egypt, Iran, India, a few Latin American countries, and the sub-Saharan African countries of Lesotho, Zambia, and Zimbabwe. Finally, Argentina, Brazil, Mexico, and Uruguay cluster in the mixed form of dual welfare states or welfare regimes (these two terms are used interchangeably). The typology of Rudra is more extended than the distinction of Haggard and Kaufman (2008) between the more protectionist regimes in Latin America and Eastern Europe and the more productivist regimes in East Asia. ${ }^{9}$

\footnotetext{
${ }^{8}$ Mauritius offers a social pension and other welfare services that go far beyond what e.g. Zimbabwe offers.

${ }^{9}$ Yet another typology by Martínez Franzoni (2008) has a stronger focus on gender aspects of (de)commodification and defamilialisation. However, the empirical base of the typology is limited to Latin American countries.
} 
In contrast to Wood and Gough (2006) and Rudra (2007), Seekings (2013) is interested in the distributional effects of welfare spending and bases his typology on social insurance and social assistance expenditures. The contributions for social insurance, whether paid by the workers themselves or paid by the government, benefit mainly former sector workers and, thus, generally not the poorest. By contrast, social assistance spending is tax-financed and potentially - depending on the tax system - more beneficial for the poorer people. The notion of social assistance is broad and includes child grants, social pensions, drought relief, and other forms (for different forms of social assistance in Botswana and South African, see the contributions of Seekings and Noyoo in this issue). His cluster analysis reveals minimalist countries with low spending on social insurance and social assistance in all regions of the world. Weakly pauperist countries (low spending on social insurance, higher on social assistance) and weakly workerist countries (the other way around) are also widespread. Strong pauperist countries with an emphasis on social assistance, however, are clearly concentrated in subSaharan Africa. Strong workerist countries, with an emphasis on social insurance, are widespread in Latin America, post-Communist Europe and Central Asia. However, again, inequality measures are not considered and there are only a few African countries included in the sample.

Whereas the typology of Esping-Andersen is, as he himself noted (1999: 73), "too narrowly based on income-maintenance programmes" and uses pension, sickness, and unemployment benefits for the decommodification index, some of the other typologies discussed above are broader. Wood and Gough (2006), Rudra (2007), Abu Sharkh and Gough (2010) all included education. Education is important for several reasons: it is generally considered as instrumental for economic growth, important for citizenship and, when publicly financed, also for equal opportunities. Generally, African countries invested a lot in education in the decade after independence and since the turn of the millennium (Künzler 2007; 2010).

A major gap is the lack of agricultural policy, a key policy domain in countries where important parts of the population live on agriculture. ${ }^{10}$ In these contexts, agricultural policies are labour market policies. Policies such as subsidies for or free distribution of agricultural inputs such as seeds or fertilizer or price control measures directly affect the welfare of peasant families. Adésínà (2015) rightly points to the importance of land reforms. Access to cultivatable land is, in several sub-Saharan African contexts (not least in South Africa, Botswana, and Namibia), a major problem, as land ownership is highly concentrated. He also mentions that African countries used marketing boards instead of pension funds to develop infrastructure, besides being a form of "social protection by other means" (Castles 1989). Furthermore, earlier work of Esping-Andersen and Korpi (1987) also suggests the inclusion of housing policies.

\section{Typologies with a focus on sub-Saharan Africa}

Education and agricultural policy are indirectly included in the typology of Mkandawire (2016), whose focus is on the ways countries were incorporated in the colonial economy. Based on the literature, especially Amin (1972), Mkandawire constructs three types: cash crop

\footnotetext{
${ }^{10}$ Seekings (2008) mentions agrarian welfare regime as predecessors of pauperist regimes but does not include any measures of agricultural policy in his subsequent work.
} 
economies, the Africa of the labour reserves, and the Africa of the concession companies. The third type, containing mainly Central African countries, is neglected in the further analysis on grounds of lacking data. In a second step, a number of variables measuring commodification, social stratification, welfare outcomes, the economic structure or the global environment are used for a cluster analysis that empirically confirms the two clusters (labour reserve economies, cash crop economies) with a few misclassified countries. A third step shows that these two types are significant predictors of the level of social expenditure.

Labour reserve economies are concentrated in Southern and Eastern Africa and include South Africa, Botswana, and Namibia. The economies of these colonies depended on cheap African wage labour. To push Africans towards wage labour, direct taxation was high and education of Africans and independent forms of income were minimised. High taxation was also needed to finance the racially exclusive welfare regimes set up for the white (male) population and enforced by a strong colonial state. The exploitation of labour was based on burdening its reproduction on rural communities kept at subsistence level. Social policy was dependent on employment in the formal sector of the economy. The poor non-employed urban population was kept to a minimum and social policies based on the English Poor Laws were targeted at this group. The legacy of high inequality and racialised social protection policies in countries such as South Africa and Namibia was a driving force behind the extension of social protection. The broader tax-base could fund the extension of social grants. However, besides these forms of social assistance, employment-based and private social insurances are still very important. The social conditions in the labour reserve economies have contributed to the high rates of HIV/AIDS in these countries. ${ }^{11}$ Consequently, some labour reserve economies fall into the Failing Informal Security Regimes type of Abu Sharkh and Gough (2010: 29). A few but by far not all labour reserve economies fit the Southern African model described by Barrientos, Hulme, and Nino-Zarazua (2009). While the authors are only partly correct in situating the emergence of this model in the 1990s, there is no doubt that non-contributory age-based income transfers are characteristic of this group of countries. These transfers are financed by domestic tax revenues and politically supported by key national actors. In a later publication, the Southern African model became the Middle Income Countries model and included Mauritius and the Seychelles (Niño-Zarazúa, Barrientos, Hickey and Hulme 2012).

Cash crop economies are mainly located in West Africa and include Francophone, Anglophone, and Lusophone countries. During colonial times, peasants had access to land and controlled their agricultural production. They were not wage labourers but participated directly in the commodity markets as producers of cotton, groundnuts, cocoa, or other export commodities. This allowed them also to invest in the education of their children, resulting in higher enrolment rates during colonial times. Social protection was community-based and this legacy of informal provision and weak institutions explains the contemporary importance of out-ofpocket expenditures. Having a weak tax base, social expenditure is generally low in these countries. Most cash crop economies fall into the Insecurity Regime type of Abu Sharkh and Gough 2010: 29). With a few outliers, they also correspond to the Middle Africa model elaborated in Barrientos, Hulme, and Nino-Zarazua (2009) and subsequently renamed Lower In-

\footnotetext{
${ }^{11}$ Many men work in mines or as seasonal farmworkers while their families stay in rural villages, sometimes in neighbouring countries. This setting is generally seen as a key factor to explain the high HIV/AIDS rates in these countries.
} 
come Countries model in Niño-Zarazúa et al. (2012). In these countries, donors, but hardly any domestic actors, initiated and financed a number of small-scale projects targeting the extremely poor (destitute households, orphans, vulnerable children). This model is characterised by a mix of poverty-based transfers that shifted from food aid to social transfers after the mid1990s and whose social and political sustainability is questionable.

As Esping-Andersen (1999: 73) noted: "Typologies are problematic because parsimony is bought at the expense of nuance, but especially because they are inherently static." In several sub-Saharan African countries, there is a considerable dynamic in social policies that is not easily captured by these typologies. The typologies discussed above include measures of who pays how much. However, Esping-Andersen was mainly interested in the characteristics of welfare programmes. Here, a key distinction is between universal and targeted social welfare. The next section turns to this aspect.

\section{Reducing inequalities with universalism or targeting?}

Although the question of whether economic inequality is rather reduced by targeted or universal social welfare programmes is widely discussed (e.g. Korpi and Palme 1998), most typologies presented in the preceding section neglect social stratification. However, recent analyses (e.g. Anttonen and Sipilä 2014; Martínez Franzoni and Sánchez-Ancochea 2014; Devereux 2016) suggest that the concept of universalism is ambiguous. This has led to the creation of the paradoxical term universalisms. An important distinction is between universal entitlement, universal targeting, and universal uptake (Leisering, Buhr and Traiser-Diop 2006). A social grant for all terrestrials would be the only programme that would be based on universal entitlement and universal targeting (for the Namibian basic income grant, see the contribution of Klocke-Daffa in this issue).

Most programmes have no universal entitlement, as they require citizenship or, rarely in sub-Saharan Africa, residence. In the strict sense, they thus have a categorical entitlement, as only members of certain social categories receive the benefits. Within these categories, all members are entitled to the benefits. A third form of entitlement is selective entitlement. Benefits are only given if members of a category fulfil certain criteria, mainly if their individual or household income is below a certain threshold. These criteria might be verified using means testing, which is expensive and requires administrative capacity (Mkandawire 2005; Pfleiderer 2013). In contexts with high poverty rates, it is also difficult and potentially divisive as people do not perceive economic differences among them (Ellis 2012). Proxy means testing is more easily assessable and, thus, cost-effective but not less difficult and divisive. It uses household characteristics such as the house construction style or assets as a proxy of the socioeconomic situation.

Moreover, targeting is universal if all entitled persons qualify for benefits. Universal targeting, thus, is not necessarily universal entitlement. Targeting is categorical if only members of a certain social group (e.g. families with children, people above or below a certain age threshold, people with residence in certain regions, people not benefitting from other transfers) benefit. It is not always easy to distinguish categorical entitlement from categorical targeting. In the first case, the category is already defined within the entitlement; in the second, it occurs after- 
wards. If citizens are entitled to a social pension without means-testing, there is a categorical entitlement (based on citizenship) and generally also categorical targeting (age threshold). Free health care for pregnant women has a categorical entitlement (all female citizens) and a categorical targeting (being pregnant).

Categorical entitlement and categorical targeting are both justified with the deservingness of the people in this category or the assumption that being part of this category is a proxy for need. ${ }^{12}$ Categories are also seen as easy to administer and, thus, efficient. However, many categorical benefits have high inclusion errors as the category frequently does not equal the condition it should target (e.g. non-poor old, non-poor rural). Categorical targeting risks providing perverse incentives as people might adapt their behaviour to become beneficiaries (Mkandawire 2005: 15). However, the reproach of perverse incentives is also addressed to universal targeting, e.g. the fostering of dependency (see the contribution of Seekings in this issue for the example of Botswana). Categorical is not to be confused with conditional: Conditional benefits are transferred if a certain action is taken (e.g. the cash grant is paid when the children are sent to school or when the pregnant woman visits a health centre for ante- and postnatal care).

Another question is who does the selection. Beneficiaries may be selected by workers of the public administration, people working for a third-party (e.g. NGO), certain members of the community or by the potential beneficiary him- or herself (Pfleiderer 2013). Targeting by public administration workers facilitates the harmonised management of social service provision on the national level but they might not be trusted and there is a potential for corruption. People working for a third party might be seen as neutral outsiders, but they are more costly. Targeting by the elders of a community or by the members of a participatory meeting reflects local understandings and is, thus, more likely to be accepted. While the administrative costs are comparatively low, this form of targeting might reinforce power structures and inequalities. Finally, self-targeting places the responsibility for claiming benefits on the target group and frequently sets them at a very low level. Benefits are often offered in particular places (e.g. slums, rural areas) to make sure that only needy people claim them. This form of targeting is also inexpensive and has the further advantage of having low inclusion errors. However, there are many exclusion errors as beneficiaries are not claimed. Self-targeting is, as other forms of targeting, generally stigmatising and detrimental to the selfrespect of the persons concerned (Mkandawire 2005: 14).

The stigmatisation is often used by proponents of universal social welfare as an argument against targeting, in addition to cost efficiency. In the 1960s and 1970s, many sub-Saharan African countries formulated tax-financed universalistic policies in the domains of education and health care, legitimised by developmentalist or other ideologies. Starting from the 1980s, there was a shift towards targeted policies (Mkandawire 2005). This shift could be observed in many countries of the Global North, but also in the countries of the Global South where it was diffused through donors such as the World Bank and the International Monetary Fund (IMF) and pushed by internal drivers. Targeting was justified with the argument that in times of

\footnotetext{
${ }^{12}$ Looking at cash transfers gives an impression of the varieties of categories used: There are cash transfers for mothers, caregivers, orphans, children, vulnerable children, adolescents, refugees, ex-combatants, people with disabilities, poor people, food-insecure people, labor-constrained people, or the elderly (Garcia and Moore 2012).
} 
economic crisis, the limited financial resources should better be targeted to the poorest. Concerning affordability, simulation models of the International Labour Organisation (ILO) have shown that basic social protection would cost a few percent of GDP, depending on the country and the package (Behrend 2008). These calculations are based on programmes designed with categorical entitlement and universal targeting. Categorical targeting would reduce the costs significantly. The decision to allocate the resources needed for basic social protection instead of, say, military expenditures is a political one. However, since the turn of the millennium, educational policies have become more universal again, but in social assistance and health care targeting still predominates.

An additional minor argument for targeting is its alleged redistributive character. However, as Skocpol (1991) and Korpi and Palme (1998) argued, the redistributive budget might be too small to erase poverty if the social groups that mostly pay for it are not potential beneficiaries and, thus, have an interest in keeping the costs down. Furthermore, if these groups are not potential beneficiaries, they turn to private offers and this generally increases inequalities. According to this paradox of redistribution (Korpi and Palme 1991), universal earnings-related social insurance programmes are best to address poverty and inequality. This kind of program is even more efficient if there is "targeting within universalism" (Skocpol 1991) or, in other words, if there are some extra benefits for the poor. However, this paradox of redistribution is somewhat difficult to transfer to a context where there are numerically not many non-poor who can finance universal earnings-related social insurance programmes whose benefits significantly reduce poverty. Indeed, many non-poor already opted out to private healthcare and pension schemes. This is relevant for the question tackled in the next section: What are the drivers of social policy in sub-Saharan Africa?

\section{Drivers of social policy}

Our review starts with the drivers discussed by Esping-Andersen and then turns to drivers mentioned in studies on sub-Saharan Africa. It is important to note that Esping-Andersen (1990) dissociated himself from the prevailing socio-economic theories. These theories explain the emergence of social policies as a reaction to social problems emerging with industrialisation. Institutions such as family-based support systems could no longer cope with a lack of employment opportunities and poverty. The coincidence of industrialisation and political modernisation, especially the democratic mass mobilisation of lower classes and nationbuilding, enabled the emergence of social policies in Western Europe (Wintermann 2005: 29). In fact, since Wilensky (1975), many comparative studies suggest that economic development is the main driver of the welfare state (for contrasting evidence, see e.g. the contribution of Seekings in this issue). It is argued that ageing societies provoke more expenditure for old age insurances, old poor, and health care. Thus, these theories expect less social expenditure in sub-Saharan Africa where the population is younger and industrialisation is less important. On the whole, these theories argue functionalist because they neglect the impact of politics and polities but emphasise automatic social change through social structural changes.

In contrast, we emphasise in the following three subsections the importance of domestic politics, influences of transnational actors, and the impact of the colonialist legacy. 


\section{Conflict theories: Power resources, political settlements, and party differences}

Conflict theories assume that social change does not automatically result in problem-solving policies. Indeed, there is variation among existing welfare states on similar levels of economic development. Lenski (1966) and Korpi (1983) explained this variation with the importance of political mobilisation based on social class, resulting in class-based distributive politics. Universal and extensive welfare systems - the social-democratic regimes of Esping-Andersen are based on strong united trade unions supporting leftist political parties. Liberal regimes emerge where the labour movement is weak and corporatist regimes where Catholic parties and institutions are strong (Esping-Andersen 1990: 134-137). However, this approach is limited to economically resourceful democratic countries with strong political parties and associations.

Looking at the organisational and conflict capacity of different groups in society and the power relations between them is the basic idea behind the political settlements approach developed by Lavers and Hickey (2016) who unsystematically use evidence from sub-Saharan Africa. It focuses on the political power struggle for and bargaining between different elite and non-elite social groups over the control and shaping of political institutions and the distribution of resources. The distribution results from the formal and informal institutions and its policies. When "key interest groups settle upon a stable set of institutions that delivers an acceptable distribution of rents" (Lavers and Hickey 2016: 391), there is a political settlement. In Western Europe, redistributive social policies were used to establish a stable political settlement between labour and capital, respectively, between left and right. In contrast, there are generally no cross-class political settlements based on redistributive social policies in subSaharan Africa. Ruling coalitions merely initiate "the expansion of social protection as a means of securing the acquiescence of groups that might otherwise threaten political stability, or to undermine political opponents" (Lavers and Hickey 2016: 391).

The effects of different kinds of ruling coalitions on social policies are discussed in studies on different types of political regimes (see Künzler 2015b). Generally, it is assumed that in competitive party systems, there is an incentive for the ruling elite for high social spending, as it buys the allegiance of the median voter who is generally poor in this context (Ha 2015: 340). Otherwise, the voters might prefer political opponents. However, there are very competitive elections without effects on social policies. Furthermore, as Feng and Gizelis (2002) argue, social policy might target less the poorest parts of the population and instead those critical for the regime (e.g. regional power base, civil servants). Accordingly, Niles (1999: 10) argues that social policy reforms are less likely in democracies with fragmented party systems where parties "cater to narrow interests" compared to stable party systems and elected authoritarian systems (see also Devereux and White 2010 and Niño-Zarazúa et al. 2012). ${ }^{13}$ The latter might have a long-term interest in broadening their support base or prevent social unrest through social protection policies (Lavers and Hickey 2016: 392). The same happens sometimes in nonelectoral regimes (Devereux and White 2010; Bender 2013; D'Arcy 2013). This puts into perspective the assumption of Niles (1999: 11) that governments of such regimes are the least

\footnotetext{
${ }^{13}$ There are different definitions for elected authoritarian systems or, as they are also called, dominant party systems (see Bogaards 2004).
} 
likely to offer social protection to their citizens. Bender (2013: 39), thus, is somewhat sceptical and argues that regime type is neither a necessary nor a sufficient condition for policy change.

This line of argument tends to underexplore the link between social policy reforms and voting behaviour, as policies might, in certain countries, explain voting behaviour less than ethnic or regional considerations. However, the coincidence of expenditures, in general (Block 2002), and social expenditures, in particular (Niles 1999), with elections is the core of the theory of political business or election cycles. There are two theoretical foundations for this approach (Block 2002). The first is based on a utilitarian conception of politicians in line with the political settlements theory presented above. The second is called the party difference approach and focuses on ideological policy preferences as reflected in the left-right continuum of political parties.

Similar to the power resource and political settlement approaches, the party difference approach also assumes that different interests and the distribution of power linked to these interests is key to understanding social policies. Countries with a stronger participation of leftist parties in government should have more redistributive social policies than countries with strong right-leaning parties. However, this approach neglects other forms of organised interests than governing parties (Wintermann 2005: 32) and overestimates the impact of ideology. Since parties in the Global South are considered less ideological (Ha 2015: 340), the approach is rarely applied to the sub-Saharan African context. At least, Seekings (2017) identifies five broad ideologies of welfare along a continuum between "an agrarian order in which poor people provide for themselves or are supported by kin" on one end and "public interventions on behalf of any people who are excluded from (or supported insufficiently by) such an agrarian order" on the other end (Seekings 2017: 10).

Starting with the kin end of the continuum, there is first a conservative-neoliberal ideology that strongly emphasises familial support and care. This ideology does not encourage an active role of the state but does not favour market-based solutions either. It is not clearly linked to particular parties, but rather to individuals and tendencies within parties, e.g. in South Africa or Zambia. As is the case with the following ideologies, the label is not used by proponents of the ideology but given by the outside observer. Second, there is a liberal-conservative ideology that also idealises the family and hard work. The state has a responsibility of providing for the poor, especially for the rural poor in periods of drought. However, market solutions are preferred over the state. As the contribution of Seekings in this issue shows, this ideology is widespread in the ruling party of Botswana. Thirdly, a conservative-productivist ideology also emphasises hard work but favours state interventions to increase economic production, especially in rural areas. Compatible with this ideology are forms of social welfare provided by the state, such as public employment programmes and investments in human capital (e.g. through sometimes conditional child grants). This ideology can be found in the ruling party of Tanzania but also within the World Bank. Seekings (2017: 20) assumes that these three ideologies prevail in much of East and Southern Africa. They share a conservative core worried about defamilialisation. "The state has a responsibility to substitute for the family (or community) when the family (or community) fails" (Seekings 2017: 25). But the state should not undermine the family by encouraging people to become disembedded actors detached from their obligations and responsibilities towards the family. This is what is criticised as dependency. 
Reciprocity is also expected in the relations between people and the state. This conservatism by members of the ruling elites does not exclude that they personally opt for private social security (pensions, health care) and, thus, follow the liberal model.

Moving more towards the public intervention end of the continuum, there is the fourth ideology: social democracy. The state is responsible for economic growth and development (this aspect is in accordance with the conservative-productivist ideology) and for the poor (this aspect is in accordance with the conservative-liberal ideology). However, deservingness is conceived more universally. This ideology predominates in the leadership of the Mauritian Labour Party and, as Künzler (forthcoming) shows, the Seychelles People's United Party and its replacements. The fifth and final ideology carved out by Seekings (2017) is a radical, rightsbased ideology that favours universal services and a more solidary society. This ideology is rarely shared by members of the ruling elites in African countries. It is sometimes nourished by theological arguments and more frequently by the staff of international NGOs and donors. The next section turns to the influence of international actors.

\section{The influence of donors and global social policy}

According to the world polity theory, many states have remarkably uniform social policy developments despite quite different levels of economic development and different institutional and cultural characteristics (Hasse 2003). This is explained as a result of the diffusion of global norms and models through international organisations and NGOs in cooperation with scientific experts. However, with regard to sub-Saharan Africa, there are clear norms and models in some social policy domains, but not in others. Education is an example where there is a clear model based on key global norms (education for all and gender parity in the educational system) established in the Millennium Development Goals and related documents. The influence of this model for the sub-Saharan African context is well documented, as is the decoupling of the goals and the actual practice (see e.g., Künzler 2007, 2010, 2015a).

In the domain of old age security, there are several subsequent models (see Künzler 2016). Since the 1940s, the ILO has supported the diffusion of its pension model that favoured a government-led pension system financed by contributions of taxation. This model was challenged from the middle of the 1990s by the three-pillar pension model of the World Bank, favouring voluntary privately funded pension accounts in addition to a low public basic pension and a mandatory private pension based on defined contributions. It is interesting to note that this model hardly diffused to sub-Saharan Africa (Kpessa and Béland 2012) where the ILO model remained more influential. After harsh criticism and in the context of a new president and internal reorganisation processes, the World Bank presented a five-pillar model in 2005. In addition to the three earlier pillars, the World Bank proposed non-contributory social pensions as zero pillar and added informal monetary or non-monetary social protection as the fourth pillar. In its more recent publications, the World Bank emphasised that there is no universal pension model that could serve as panacea (Wodsak 2011: 359). However, noncontributory social pensions are globally recognised and supported not only by the World Bank but also by other international actors such as the ILO or HelpAge International.

In the domain of health care, there are even less clear global models. The influential Alma Ata Declaration of 1978 is quite vague about the meaning of several of its key concepts. How- 
ever, universal health policies came increasingly under pressure, and the Bamako Initiative in 1987 was implemented in a quite selective way, frequently meaning higher out-of-pocket health costs for individuals. In the context of structural adjustment programmes the IMF and the World Bank became more influential in the health sector. They encouraged fees for health services and private healthcare facilities in the 1980s and 1990s without advocating a clear model. Neither is such a clear dominant model emerging from other organisations. In another domain of social policy, social assistance, there is even less of a global model (Leisering, Buhr and Diop 2006). The result is a low influence of international actors and diverse policies at the national level.

Studies analysing the influence of donors on national level policies show ambiguous evidence. Donors pushed for social policy reforms when imposing structural adjustment and conditionalities on African countries (D'Arcy 2013: 221), or when promoting cash transfers in recent years (Seekings 2013: 318). They are also likely to be influential in certain post-conflict settings (Cometto, Fritsche and Sondorp 2010). Furthermore, donors can be in opposition to social policy reforms (Cometto et al. 2010; Devereux and White 2010: 65). However, their influence might be somewhat limited because of the weight of national political institutions and actors (D'Arcy 2013: 221). “The influence of external actors works best where engagement with domestic political and policy processes enable stronger ownership of social protection programmes by national governments, public administrations, and political constituencies, and where external knowledge is framed as learning rather than policy transfer" (NiñoZarazúa et al. 2012: 169). Donors have limited influence if they neglect domestic politics or the perspective of the national political elite, which frequently focuses on national development based on economic growth and, as mentioned, worries about defamilialisation.

Niño-Zarazúa et al. (2012: 169) point to the importance of framing external knowledge as "learning rather than policy transfer". Indeed, cross-national policy learning is another way social policies diffuse from one country to another. Policy-learning is a notion that is far more used than defined and the conditions necessary for policy learning to happen are unclear. Policy learning happens frequently from neighbouring countries (Schmitt et al. 2015: 515, see Casey and McKinnon 2009 for social pensions in Southern Africa). Beyond drawing lessons from them, policy changes in neighbouring countries may also be taken up by political or civil society actors to generate reform pressure on governments or parties (D'Arcy 2013). Beyond neighbouring countries and through global models, policies also diffuse from south to south, e.g. between Brazil and some African countries (Niño-Zarazúa et al. 2012: 169). Finally, there is "parallel thinking" when similar circumstances and problem definitions trigger similar policies (Marmor, Freeman and Okma 2005: 337).

\section{Inheriting policies and path dependency}

When politicians enter office, they inherit a number of policies and institutions from their predecessors. This inheritance shapes the further development of policies because there is a "dynamic of 'increasing returns" (Pierson 2000: 251), or in other words, path dependency. Sticking to established policy frameworks becomes more and more probable because the costs of switching to another framework increase over time. There is, thus, a self-reinforcing feedback process that makes it difficult and expensive to reverse a course of action initiated. This 
favours incrementalist change. However, this approach tends to depict the policy space too limited and neglects contemporary forces shaping policy choice.

For the sub-Saharan African context, there is empirical evidence for path dependency in social policy. Many concepts of social protection introduced by colonial administrations shaped post-colonial social policy developments (e.g. Kangas 2012; Schmitt 2015).

With the exception of Madagascar (labour reserve) and three Central African colonies dominated by concessions, French colonies were mainly cash crop economies. Contrary to the assumption of Mkandawire (2015), the cash crop economies had at independence lower enrollment rates compared to the colonies dominated by concessions and, within both groups, there were considerable differences (Künzler 2007). However, there is no clear pattern of educational path dependency among the post-colonial states. French colonial administration was quite centralist and claimed an active role in developing social and economic planning (MacLean 2002; Kangas 2012; Schmitt 2015). As colonies were conceived as extensions of France, key social policies were fairly independent of the economic prosperity of the respective colonies and from their pre- and para-colonial forms of social protection. Predominantly Catholic France had a special emphasis on family allowances and, when reforming its family allowance system, expanded it to North Africa in the 1940s and subsequently to other colonies. In contrast, only a few rather industrialised colonies adopted old age benefits early - others followed after independence. They were insurance-based and covered only a privileged group of mainly urban formal sector workers. However, most French colonies had corporatist social insurance for formal sector workers in the domain of sickness, maternity, and employment injury.

Belgian colonialism had similarities to French colonialism. In the domains of occupational risks and old age benefits, the social security system of Belgium was copied both in the labour reserve territory Ruanda-Urundi and in the Congo where concessions dominated. While occupational risks were covered quite early to stabilise the labour force, old age benefits were implemented just before independence, but with remarkable benefits (Iliffe 1987: 208). Educational policies were more diverse. Again partly contrary to the assumption of Mkandawire (2015), the Belgian labour reserve territory Ruanda-Urundi, today Rwanda and Burundi, had quite different primary education enrolments. The Congo had rather high primary education enrolments but offered almost no further education to Africans. Again, there is no clear pattern of educational path dependency among the post-colonial states.

This is also the case for another concession economy that had one of the highest GNPs at independence and is one of only two African territories with Spanish colonial heritage: Equatorial Guinea. Spanish colonies had a focus on old age provision (Schmitt 2015) and Equatorial Guinea introduced old age provision quite early, compared to the sub-Saharan African context (but later than in Latin America).

The colonial social policy legacy of Portuguese colonialism did, to our knowledge, not receive systematic attention. ${ }^{14}$ Forced labour was usual in all Portuguese colonies for much longer than in other colonies. Portuguese Guinea, today called Guinea-Bissau, was a neglected cash crop economy. São Tomé and Príncipe was a plantation economy of the Central African type. To some extent, Cape Verde was a labour reserve. According to Mkandawire (2016:2),

\footnotetext{
${ }^{14}$ Our focus on the formative years of colonial social policies neglects Italian colonies.
} 
Angola and Mozambique are also labour reserves. However, Mozambique and Angola were rather mixtures of all categories, as they were partly also plantation and cash crop economies. By far, the highest percentage of European population was living in Angola, which was also the most developed colony. Consequently, while African educational enrolment was low until the final years of colonialism, employment linked social security was introduced in the 1950s. In contrast, this happened later in Mozambique where enrolment was somewhat higher. It is reasonable to assume there is no single pattern of Portuguese colonial social policy and of path dependency among post-colonial states.

As Portugal, and in contrast to France and Belgium, the British Empire had a decentralised imperial strategy and a more passive understanding of the role of the colonial administration for social security. Colonies were required to finance their social policies from their own resources (MacLean 2002; Schmitt 2015: 332), leading to a more heterogeneous social protection than among the French colonies -both between and within British colonies. Some African territories (Mauritius, South Africa) introduced non-contributory and, thus, redistributive old age pensions (Seekings 2008). However, many former British colonies introduced social protection for old age not until after achieving independence. Some British colonies introduced provident funds for formal sector workers (Schmitt 2015: 335). Still anticipating a return to rural villages after retirement, these retirement schemes provided lumpsum payments and did not require large contributions by the government. Other former British colonies chose flat-rate pensions or earnings-related pension schemes. All these schemes are not redistributive. A particularity of British colonies were non-contributory schemes for civil servants. While there are, thus, corporatist elements in British colonial social policies, these are stronger in French colonies.

\section{Conclusion}

This article is interested in the character of welfare regimes in sub-Saharan Africa and the usefulness of Esping-Andersen's key categories for this context. To start with the second question: decommodification and defamilialisation, two key concepts of Esping-Andersen, are not very helpful to distinguish welfare regimes in sub-Saharan Africa. Participation in the formal labour market is generally less important than other ways of earning a livelihood. However, South Africa and Namibia are among the sub-Saharan African countries having a comparatively old population and offering social pensions. This is possible because the comparatively high share of formal sector employment contributes to a tax base broad enough to finance such universal social policies. Thus, decommodification is based on comparatively high commodification in the sense of high formal employment. Of course, more importantly for the formal sector workers' own welfare are the social insurances linked to their employment. In other countries, there is not enough non-poor participation in the labour market to finance universal policies offering benefits high enough to pull beneficiaries out of poverty. For the sub-Saharan African context, it is, thus, important to conceptually delink commodification from market-based social welfare. Defamilialisation is a useful concept to describe the core of the dominant ideology of welfare in Eastern and Southern Africa according to Seekings (2017). The state is expected to substitute for the family only when it fails, but primarily pro- 
tects the family by avoiding social policies that encourage people to become disembedded actors. Finally, the third key concept of Esping-Andersen, social stratification, is hardly considered in comparative research on sub-Saharan Africa. This is a pity because especially the Southern African societies are strongly stratified and have high income and wealth inequalities. However, in contrast to Latin America, probably owing to a lack of data on most African countries, economic inequalities are still no dimension in current typologies.

In consequence, and this leads us to the first question, there is no typology of African states that covers all relevant dimensions of welfare and includes education, agricultural, and housing policies. Besides neglecting economic inequalities and important policies, the global typologies have a number of other shortcomings. Considering most sub-Saharan African countries as Insecurity Regimes is at most appropriate to position the welfare efforts of African countries in comparison to other regions, but is generally not very helpful for describing differences between African countries. Moreover, Rudra's (2007) typology includes only very few African countries and has some strange bedfellows in the same cluster. The same is true for Seeking's (2013) typology. However, the basic distinction between tax-financed social assistance and social insurance financed by contributions is useful. Indeed, not only the finance part is important for the question "who gets what?" but also the design of the social policy instruments.

These conceptual tools are helpful for a second look at Mkandawire's (2015) typology based on colonial heritage. Looking at his cash crop economies and concession areas (and still neglecting education, health care, and other forms of social security), they focus on selective forms of social assistance. Such forms also exist in labour reserve economies. However, instruments with categorical entitlement and targeting are limited to some labour reserve economies. There are non-contributory social pensions in Botswana, Cape Verde, Lesotho, Mauritius, Namibia, Seychelles, South Africa, and Swaziland (see Künzler 2016). ${ }^{15}$ Mkandawire offers no tools to explain why certain labour economies have social pensions and others such as Kenya, Malawi, Zambia, or Zimbabwe do not.

For this question, a look at the drivers of social policies might be useful. However, current approaches are generally based on case studies or impressionistic evidence. A first study that systematically looks for contrasting cases (Künzler 2015b) showed that there is no single factor that can explain all social policy reforms - there is definitely more than one way to skin a cat. Different configurations of factors seem to promote social policy reforms. One configuration that explains social policy reforms is a combination of supportive donors and the absence of other donors opposed to the reform. It is, thus, not only important that a social policy reform conforms to domestic priorities, but also that there are no other donors offering significant support for alternative policies. Another, rather surprising configuration that explains social policy reforms is the combination of lacking resources with lacking power changes. Thus, presidents of non-elected or elected authoritarian regimes often have an interest in social policy reforms even when there are no resources. A final configuration with rather limited explanatory power for successful reforms is a double window of opportunity, where a power change coincided with available resources. Finally, social assistance reforms are more likely to

\footnotetext{
${ }^{15}$ This list does not include any former French colony. However, Algeria also has a social pension.
} 
happen where resources are available. Available resources go together with supporting donors in the sample. A power change has somewhat limited explanatory power for successful reforms in combination with available resources; incumbents, however, are not among the drivers of reforms in our sample.

As the discussion about the effect of different types of political regimes already suggested, there is no simple empirical relation between regime type and social policies (Künzler 2015b). This empirically confirms what Bender (2013: 39) concluded based on a review of anecdotal country examples from Latin America and Asia: Political regime type is neither a necessary nor a sufficient condition for social policy change. Also, election cycles are neither necessary nor sufficient conditions for social policy change. Systematic research is needed to examine whether incumbents only opt for social policy reforms when they feel under pressure (tight electoral competition, uncertain majorities, and risk of losing power). Finally, for an explanation why certain labour economies have social pensions and others not, we need to include different forms of entitlement and targeting in future research. There is no doubt that social policies in sub-Saharan African countries got more scientific attention in recent years. However, the question of how to classify their welfare regimes and the drivers of social policies demands further research.

\section{References}

Abu Sharkh, Miriam and Ian Gough (2010). Global Welfare Regimes. A Cluster Analysis. Global Social Policy, 10(1), 27-58.

Adésínà, Jìmí O. (2015). Return to a Wider Vision of Social Policy: Re-reading Theory and History. South African Review of Sociology, 46(3), 99-119.

Amin, Samir (1972). Underdevelopment and Dependence in Black Africa - Origins and Contemporary Forms. The Journal of Modern African Studies, 10(4), 503-524.

Anttonen, Anneli and Jorma Sipilä (2014). Varieties of Universalism. Draft paper prepared for the UNRISD Conference New Directions in Social Policy: Alternatives from and for the Global South 7-8 April, 2014, Geneva, Switzerland, available at http://www.unrisd.org/80256B3C005BCCF9/(httpAuxPages)/D04EC7C33C9EC48AC1257D08002 93153/\$file/Anttonen\%20and\%20Sipila.pdf, last accessed 5 October 2017.

Bambra, Clare (2004). The worlds of welfare: illusory and gender blind? Social Policy and Society, 3(3), 201-211.

Bambra, Clare (2007). Defamilisation and welfare state regimes: a cluster analysis. International Journal of Social Welfare, 16(4), 326-338.

Barrientos, Armando, David Hulme and Miguel Nino-Zarazua (2009). Will the Green Shoots Blossom? A New Wave of Social Protection in Sub-Saharan Africa. Manchester: Brooks World Poverty Institute.

Behrendt, Christina (2008). Can Low Income Countries in Sub-Saharan Africa Afford Basic Social Protection? First Results of a Modelling Exercise. In: Barrientos, Armando and David Hulme (eds.): Social Protection for the Poor and the Poorest (282-299). Basingstoke: Palgrave Macmillan. 
Bender, Katja (2013). The Political Economy of Social Protection Reforms in Developing Countries. What is to be explained and how? In: Bender, Katja, Markus Kaltenborn and Christian Pfleiderer (eds.): Social Protection in Developing Countries. Reforming Systems (33-42). London/New York: Routledge.

Bevan, Philippa (2004). The dynamics of Africa's in/security regimes. In: Gough, Ian and Geof Wood with Armando Barrientos, Philippa Bevan, Peter Davis and Graham Room: Insecurity and Welfare Regimes in Asia, Africa and Latin America. Social Policy in Development Contexts (202-252). Cambridge: Cambridge University Press.

Block, Steven A. (2002). Political business cycles, democratization, and economic reform: the case of Africa. Journal of Development Economics, 67, 205-228.

Bogaards, Matthijs (2004). Counting parties and identifying dominant party systems in Africa. European Journal of Political Research, 43, 173-197.

Casey, Bernard H. and Roddy McKinnon (2009). Social pensions and policy learning: The case of southern Africa. International Social Security Review, 62(4), 81-102.

Castles, Francis G. (1989). Social protection by other means. In: Castles, Francis G. (ed.): The Comparative History of Public Policy (16-55). New York: Oxford University Press.

CIA World Factbook (n.d.). Median Age. Dataset available at https://www.cia.gov/library/publications/the-world-factbook/fields/2177.html, last accessed 29 September 2017.

Cometto, Giorgio, Gyuri Fritsche and Egbert Sondorp (2010). Health sector recover in early postconflict environments: experience from southern Sudan. Disasters, 34(4), 885-909.

Danforth, Benjamin (2014). Worlds of Welfare in Time: A Historical Reassessment of the ThreeWorld Typology. Journal of European Social Policy, 24(2), 164-182.

D'Arcy, Michelle (2013). Non-state actors and universal services in Tanzania and Lesotho: state-building by Alliance. Journal of Modern African Studies, 51(2), 219-247.

Deeming, Christopher (2017). The Lost and New 'Liberal World' of Welfare Capitalism: A Critical Assessment of Gøsta Esping-Andersen’s The Three Worlds of Welfare Capitalism a Quarter Century Later. Social Policy \& Society, 16(3), 405-422.

Devereux, Stephen (2016). Is targeting ethical? Global Social Policy, 16(2), 166-181.

Devereux, Stephen and Philip White (2010). Social Protection in Africa: Evidence, Politics, and Rights. Poverty \& Public Policy, 2(3), 53-77.

Ellis, Frank (2012). 'We are all poor here': Economic Difference, Social Divisiveness and Targeting Cash Transfers in Sub-Saharan Africa. Journal of Development Studies, 48(2), 201-214.

Esping-Andersen, Gøsta (1990). The Three Worlds of Welfare Capitalism. Cambridge: Polity Press.

Esping-Andersen, Gøsta (1999). Social Foundations of Postindustrial Economies. Oxford: Oxford University Press.

Esping-Andersen, Gøsta and Walter Korpi (1989). From Poor Relief to Institutional Welfare States: The Development of Scandinavian Social Policy. In: Erikson, Robert, Erik Jørgen Hansen, Stein Ringen and Hannu Uusitalo (eds.): The Scandinavian Model. Welfare States and Welfare Research (39-74). Armonk/London: M.E. Sharpe. 
Garcia, Marito and Charity M.T. Moore (2012). The Cash Dividend. The Rise of Cash Transfer Programs in sub-Saharan Africa. Washington: World Bank.

Ha, Eunyoung (2015). The impact of democracy, government ideology, and globalization on social spending in less developed countries. International Journal of Comparative Sociology, 56(5), 338365.

Haggard, Stephan and Robert R. Kaufman (2008). Development, Democracy, and Welfare States: Latin America, East Asia, and Eastern Europe. Princeton: Princeton University Press.

Hasse, Raimund (2003). Wohlfahrtspolitik und Globalisierung. Zur Diffusion der World Polity durch Organisationswandel und Wettbewerbsorientierung. Opladen: Leske + Budrich.

Iliffe, John (1987). The African Poor: A history. Cambridge: Cambridge University Press.

ILO (2013). Women and Men in the Informal Economy: A Statistical Picture. Second Edition. Geneva: International Labour Office. Available at http://www.ilo.org/wcmsp5/groups/public/---dgreports/--stat/documents/publication/wcms 234413.pdf, last accessed 28 September 2017.

Kangas, Olli E. (2012). Testing old theories in new surroundings: The timing of first social security laws in Africa. International Social Security Review, 65(1), 73-97.

Korpi, Walter (1983). The Democratic Class Struggle. London: Routledge \& Kegan Paul.

Korpi, Walter and Joakim Palme (1998). The Paradox of Redistribution and Strategies of Equality: Welfare State Institutions, Inequality, and Poverty in the Western Countries. American Sociological Review, 63(5), 661-687.

Kpessa, Michael and Daniel Béland (2012). Transnational actors and the politics of pension reform in Sub-Saharan Africa. Review of International Political Economy, 19(2), 267-291.

Künzler, Daniel (2007). L'éducation pour quelques-uns? Enseignement et mobilité sociale en Afrique au temps de la privatisation: le cas du Bénin. Paris: L'Harmattan.

Künzler, Daniel (2010). Bildungskonvergenz in der globalen Gesellschaft? In: Gächter, August, Franz Kolland, Petra Dannecker and Christian Suter (eds.): Soziologie der globalen Gesellschaft. Eine Einführung (209-234). Wien: Mandelbaum Verlag.

Künzler, Daniel (2015a). Kontinuität, Konvergenz oder Divergenz? Veränderungen und Beständigkeiten in der globalen Bildungsdiskussion. In: Faschingeder, Gerald und Franz Kolland (eds.). Bildung und ungleiche Entwicklung. Globale Konvergenzen und Divergenzen in der Bildungswelt (18-32). Wien: New Academic Press.

Künzler, Daniel (2015b). A Qualitative Comparative Analysis of political drivers of social policy reforms in sub-Saharan Africa. Paper presented at the Annual RC19 Conference August 26-28 at the University of Bath, UK.

Künzler, Daniel (2016). Health Care and Old Age Pensions in Latin America and Africa: Introduction to the Issue. socialpolicy.ch, 1/2016, Article 1.1.

Künzler, Daniel (forthcoming). The persistence of social policy after the socialist revolution in the Seychelles. socialpolicy.ch, 1/2018.

Lavers, Tom and Sam Hickey (2016). Conceptualising the politics of social protection expansion in low income countries: The intersection of transnational ideas and domestic politics. International Journal of Social Welfare, 25, 388-398. 
Leisering, Lutz, Petra Buhr and Ute Traiser-Diop (2006). Soziale Grundsicherung in der Weltgesellschaft. Monetäre Mindestsicherungssysteme in den Ländern des Südens und des Nordens. Weltweiter Survey and theoretische Verortung. Bielefeld: transcript.

Lenski, Gerhard (1966). Power and Privilege: A Theory of Social Stratification. New York: McGraw-Hill Book Company.

Mandel, Hadas (2009). Configurations of gender inequality: the consequences of ideology and public policy. British Journal of Sociology, 60(4), 693-719.

Marmor, Ted, Richard Freeman and Kieke Okma (2005). Comparative Perspectives and Policy Learning in the World of Health Care. Journal of Comparative Policy Analysis: Research and Practice, 7(4), 331-348.

Martínez Franzoni, Juliana (2008). Capturing Constellations of Markets, Families, and Policies. Latin American Politics and Society, 50(2), 67-100.

Martínez Franzoni, Juliana and Diego Sánchez-Ancochea (2014). Should Policy Aim at Having All People on the Same Boat? The Definition, Relevance and Challenges of Universalism in Latin America. Working Paper No. 70. Berlin: desiguAldades.net.

Mkandawire, Thandika (2005). Targeting and Universalism in Poverty Reduction. Social Policy and Development Programme Paper Number 23. Geneva: UNRISD.

Mkandawire, Thandika (2016). Colonial Legacies and Social Welfare Regimes in Africa. An Empirical Exercise. Working Paper 2016-4. Geneva: UNRISD.

Niles, Kimberley J. (1999). Economic Adjustment and Targeted Social Spending: The role of Political Institutions. Paper prepared for the World Development Report 2001 meetings, August 16-17, Castle Donington. Available at

http://web.iaincirebon.ac.id/ebook/moon/PoliticalScience/NILES_POLINSTITUTION.PDF, last accessed 2 July 2014.

Niño-Zarazúa, Miguel, Armando Barrientos, Samuel Hickey and David Hulme (2012). Social Protection in Sub-Saharan Africa: Getting the Politics Right. World Development, 40(1), 163-176.

Nollert, Michael (2006). Sonderfall im rheinischen Kapitalismus oder Sonderweg im liberalen Wohlfahrtskapitalismus? Zur Spezifität des Sozialstaats Schweiz. In: Eberle, Thomas and Kurt Imhof (eds.): Sonderfall Schweiz (153-171). Zürich: Seismo.

Pierson, Paul (2000). Increasing Returns, Path Dependency, and the Study of Politics. American Political Science Review, 94(2), 251-267.

Pfleiderer, Christian (2013). How to target. Overview on current targeting methods in social protection. In: Bender, Katja, Markus Kaltenborn and Christian Pfleiderer (eds.): Social Protection in Developing Countries. Reforming systems (134-145). London/New York: Routledge.

Rudra, Nita (2007). Welfare States in Developing Countries: Unique or Universal? Journal of Politics, 69(2), 378-396.

Salamon, Lester M., Wojciech Sokolowski and Megan A. Haddock (eds.) (2017). Explaining Civil Society Development. A Social Origins Approach. Baltimore: Johns Hopkins University Press.

Schmitt, Carina (2015). Social Security Development and the Colonial Legacy. World Development, 70, 332-342. 
Seekings, Jeremy (2008). Welfare Regimes and Redistribution in the South. In: Shapiro, Ian, Peter A. Swenson and Daniela Donno (eds.): Divide and Deal. The Politics of Distribution in Democracies (19-42). New York/London: New York University Press.

Seekings, Jeremy (2013). Welfare regimes and distribution across the global South: Theory and evidence in the construction of typologies. Working paper.

Seekings, Jeremy (2017). Ideologies of Welfare in Africa. Paper presented at the Annual Meeting of ISA RC19, 22-25 June 2017, University of North Carolina, Chapel Hill, USA.

Seekings, Jeremy and Nicoli Nattrass (2015). Policy, Politics and Poverty in South Africa. Basingstoke: Palgrave Macmillan.

Skocpol, Theda (1991). Universal Appeal. Politically Viable Policies to Combat Poverty. The Brookings Review, Summer, 29-33.

United Nations UN (2015): Sustainable Development Goals. Available at https://www.un.org/sustainabledevelopment/, last accessed 5 October 2017.

Wilensky, Harold L. (1975). The Welfare State and Equality: Structural and ideological roots of public expenditures. Berkeley: University of California Press.

Wintermann, Ole (2005). Vom Retrenchment zur Krisenreaktionsfähigkeit. Ein empirischer Vergleich der Wohlfahrtsstaaten Schweden und Deutschland, 1990-2000. Wiesbaden: VS Verlag für Sozialwissenschaften.

Wodsak, Veronika (2011). Wandel und Kontinuität in der globalen Alterssicherungsdebatte: Die Rolle der Weltbank. In: Leisering, Lutz (ed.): Die Alten der Welt. Neue Wege der Alterssicherung im globalen Norden und Süden (343-374). Frankfurt am Main: Campus.

Wood, Geof and Ian Gough (2006). A Comparative Welfare Regime Approach to Global Social Policy. World Development, 34(10), 1696-1712. 